\title{
Utilization of Palm Oil Fuel Ash as Binder in Lightweight Oil Palm Shell Geopolymer Concrete
}

\author{
Michael Yong Jing Liu, Choon Peng Chua, U. Johnson Alengaram, \\ and Mohd Zamin Jumaat \\ Department of Civil Engineering, Faculty of Engineering, University of Malaya, 50603 Kuala Lumpur, Malaysia \\ Correspondence should be addressed to U. Johnson Alengaram; ujohnrose@yahoo.com
}

Received 20 October 2013; Accepted 16 December 2013; Published 9 January 2014

Academic Editor: Jacques Huot

Copyright (C) 2014 Michael Yong Jing Liu et al. This is an open access article distributed under the Creative Commons Attribution License, which permits unrestricted use, distribution, and reproduction in any medium, provided the original work is properly cited.

Traditionally fly ash (FA) has been used to replace cement as binder in the geopolymer concrete. The utilization of palm oil industrial waste materials known as palm oil fuel ash (POFA) and oil palm shell (OPS) that are abundantly available in South East Asia as binder and coarse aggregate in geopolymer concrete would give an added advantage in both the environmental and economic aspects. The mechanical properties of the OPS geopolymer concrete (OPSGC) through the use of POFA, FA, and OPS are investigated and reported. A total of ten OPSGC mixtures were prepared with varying percentages of POFA and FA such as 0, $10,20,40$, and $100 \%$. The specimens prepared with two alkaline solution to binder (AK/B) ratios of 0.35 and 0.55 were oven cured at $65^{\circ} \mathrm{C}$ for 48 hours. The experimental results showed that the highest compressive strength of $30 \mathrm{MPa}$ was obtained for the mix with $20 \%$ replacement of FA by POFA and AK/B ratio of 0.55 , which underwent oven curing. Further, the mix of up to $20 \%$ POFA (with $\mathrm{AK} / \mathrm{B}$ ratio of 0.55 ) can be categorized as structural lightweight concrete. An increase of the POFA content beyond $20 \%$ decreases the mechanical properties, and hence this mix is recommended to be used.

\section{Introduction}

Cement is an indispensable material in the development of concrete even though the conventional concrete is made of composite materials such as fly ash, ground granulated blast furnace slag, and silica fume. The use of ordinary Portland cement (OPC) was not environmental friendly and caused adverse effect, resulting from the energy intensive and greenhouse effects [1]. Davidovits [2] was the pioneer in introducing binders other than cement that could be produced by the reaction between alkaline solution $(\mathrm{AK})$ and source materials that are rich in silica $\left(\mathrm{SiO}_{2}\right)$ and alumina $\left(\mathrm{Al}_{2} \mathrm{O}_{3}\right)$, commonly known as geopolymerization. In comparison with the normal concrete, the geopolymer concrete has more factors that affect its properties due to the use of AK. Sathonsaowaphak et al. [3] reported that the geopolymer mortar with AK/B ratios of $0.43-0.71$ achieved compressive strength of $42-52 \mathrm{MPa}$ by using FA and bottom ash as binders. Furthermore, geopolymer concrete could achieve high early compressive strength when oven cured, instead of undergoing ambient curing [4].

Since Malaysia is the second largest palm oil producer, the leftover agricultural wastes have been cumulative and caused land and air pollution in the vicinity of the palm oil factories. Many researchers have taken the initiative to utilize the palm oil industrial wastes, such as OPS and POFA, to develop sustainable construction material. Shafigh et al. [5] reported that by crushing the larger original OPS aggregate, a high 28day compressive strength of $53 \mathrm{MPa}$ of oil palm shell concrete (OPSC) can be obtained. Additionally, by adding foam in the OPSC to reduce its density, a structural lightweight concrete (LWC) can be produced with a $39 \%$ of reduced thermal conductivity compared to the conventional brick [6]. Moreover, Yap et al. [7] investigated that the addition of polypropylene and nylon fibres in the OPSC enhanced the postfailure compressive strength. Depending on the fineness and percentage of cement replacement, POFA as cement replacement enables longer initial and final setting times [8]. 
Sata et al. [9] reported that replacing POFA, as cement of up to $30 \%$ can produce high strength concrete of about $86 \mathrm{MPa}$.

Furthermore, the use of geopolymer technology in concrete, which incorporates waste materials such as FA, POFA and OPS, will be an added advantage in construction industry especially in terms of environmental and economic aspects. Raden and Hamidah [10] made an effort to utilize waste paper sludge ash as a source material to develop foamed geopolymer concrete (FGC). The density and the compressive strength of FGC were found to be approximately $1800 \mathrm{~kg} / \mathrm{m}^{3}$ and $3 \mathrm{MPa}$, respectively. Kupaei et al. [11] produced a structural grade of $30 \mathrm{MPa}$ by incorporating OPS as lightweight aggregate (LWA) in geopolymer concrete. Ariffin et al. [12] reported that the geopolymer concrete using FA and POFA as binders is more durable when exposed to the sulphuric acid, compared to the OPC concrete. The abundance of the agricultural wastes such as POFA and FA in South East Asia enables researchers to utilize these materials as binders in the development of geopolymer concrete by using OPS as LWA. There has been no research carried out in the past incorporating POFA and OPS in the geopolymer concrete.

This research work aims to develop geopolymer concrete by utilizing the local industrial wastes such as FA and POFA as binders and the OPS as coarse aggregate. This novel geopolymer concrete is christened as oil palm shell geopolymer concrete (OPSGC). The variables investigated are the percentages of POFA and FA and the curing regimes, namely, oven and ambient curing; the other variable investigated includes the AK/B ratios ( 0.35 and 0.55$)$ by mass. The compressive strengths at different ages of $3,7,14$, and 28 days were tested and reported in this investigation. In addition, the 28-day splitting tensile and flexural strengths of the OPSGC are also reported.

\section{Experimental Procedures}

2.1. Materials. The binders used in this experimental work are class-F FA and POFA, whose the chemical compositions are shown in Table 1 which conform to the ASTM C618 [13]. The POFA collected from the local palm oil mill was oven dried at $105 \pm 5^{\circ} \mathrm{C}$ for 24 hours, followed by sieving through $300 \mu \mathrm{m}$ to remove any coarse foreign particles. Then, the POFA was ground to a mean particle size of $45 \mu \mathrm{m}$ by using the Los Angeles (LA) abrasion machine for 30,000 cycles, to enhance the fineness and reactivity. The speed of the LA abrasion machine was about 33 revolutions per minute (rpm).

The use of POFA as binder satisfies the chemical requirement in ASTM C618 [13] as pozzolanic material by having loss on ignition (LOI) of less than $10 \%$; thus, it could be beneficial in the manufacture of concrete. Sata et al. [9] and Hussin and Ishida [14] reported that the POFA concrete exhibited consistent strength development after 3 days, indicating no deterioration over time.

The crushed OPS of sizes between 2.36 and $9.5 \mathrm{~mm}$ with saturated surface dry (SSD) condition was used as the coarse LWA in this study. Table 2 shows the physical properties of the OPS. Mining sand with a specific gravity of 2.67 , passing through $5 \mathrm{~mm}$ and retained on $300 \mu \mathrm{m}$, was used as the fine
TABLE 1: Chemical composition (\%) of class-F FA and POFA.

\begin{tabular}{lcccccccc}
\hline & $\mathrm{SiO}_{2}$ & $\mathrm{Al}_{2} \mathrm{O}_{3}$ & $\mathrm{Fe}_{2} \mathrm{O}_{3}$ & $\mathrm{CaO}$ & $\mathrm{MgO}$ & $\mathrm{K}_{2} \mathrm{O}$ & $\mathrm{SO}_{3}$ & $\mathrm{LOI}$ \\
\hline Class-F FA & 57.6 & 28.9 & 5.8 & 0.2 & 0.9 & 0.9 & 0.2 & 3.6 \\
POFA & 63.4 & 5.5 & 4.2 & 4.3 & 3.7 & 6.3 & 0.9 & 6.0 \\
\hline
\end{tabular}

TABle 2: Physical properties of OPS.

\begin{tabular}{lc}
\hline Physical property & OPS \\
\hline Specific gravity (saturated surface dry) & 1.36 \\
Bulk density (loose) $\left(\mathrm{kg} / \mathrm{m}^{3}\right)$ & 589 \\
Bulk density (compacted) $\left(\mathrm{kg} / \mathrm{m}^{3}\right)$ & 652 \\
Fineness modulus & 5.90 \\
Water absorption $(24 \mathrm{~h})(\%)$ & 24.39 \\
\hline
\end{tabular}

TABLE 3: Variables investigated on the OPSGC.

\begin{tabular}{lcccc}
\hline Mixture & POFA $(\%)$ & FA $(\%)$ & AK/B & Curing method \\
\hline M1 & 0 & 100 & 0.55 & Oven \\
M2 & 10 & 90 & 0.55 & Oven \\
M3 & 20 & 80 & 0.55 & Oven \\
M4 & 40 & 60 & 0.55 & Oven \\
M5 & 100 & 0 & 0.55 & Oven \\
M2-A & 10 & 90 & 0.55 & Ambient \\
M1-2 & 0 & 100 & 0.35 & Oven \\
M2-2 & 10 & 90 & 0.35 & Oven \\
M3-2 & 20 & 80 & 0.35 & Oven \\
M4-2 & 40 & 60 & 0.35 & Oven \\
M5-2 & 100 & 0 & 0.35 & Oven \\
\hline
\end{tabular}

aggregate. The fineness modulus of the OPS was determined in accordance with ASTM C136 [15]. Since the fineness modulus of OPS is uniform similar to the normal weight aggregate (e.g., granite), Alengaram et al. [16] reported that the OPS can be used as coarse aggregate.

As for the alkaline activator, a combination of sodium hydroxide $(\mathrm{NaOH})$ in flake form and sodium silicate $\left(\mathrm{Na}_{2} \mathrm{SiO}_{3}\right)$ solution was used in this investigation, where the molarity of the $\mathrm{NaOH}$ was kept constant at $14 \mathrm{M}$. The solution was prepared at least 1 day prior to its use to allow the exothermically heated liquid to cool to ambient temperature. The ratios of the $\mathrm{Na}_{2} \mathrm{SiO}_{3}$ solution to $\mathrm{NaOH}$ solution and the AK/B were 2.5 and 0.55 or 0.35 by mass, correspondingly. Additionally, a polycarboxylate ether (PCE) based superplasticizer (SP) was used at a dosage of $1.5 \%$ by mass of binders, to improve the workability. Potable water was used in all the mixes and the ratio of additional water to binders was maintained at 0.1 .

2.2. Mix Proportions and Specimen Preparation. The variables that are investigated in this research are shown in Table 3, while the respective mixture proportions are shown in Table 4. The effect on OPSGC with different percentages of POFA and FA $(0 \%, 10 \%, 20 \%, 40 \%$, and $100 \%)$ is investigated and reported. Other than that, the curing methods (oven and ambient curing) and ratios of $\mathrm{AK} / \mathrm{B}$ (0.55 and 0.35$)$ by mass, 
TABLE 4: Mixture proportions of the OPSGC.

\begin{tabular}{|c|c|c|c|c|c|c|c|}
\hline \multirow{2}{*}{ Mixture } & \multicolumn{7}{|c|}{ Mix proportions $\left(\mathrm{kg} / \mathrm{m}^{3}\right)$} \\
\hline & POFA & FA & Sand & OPS & $\mathrm{AK}$ & Water & SP \\
\hline M1 & 0.0 & 483.8 & 822.5 & 290.3 & 266.1 & 72.6 & 7.3 \\
\hline M2 & 48.7 & 437.9 & 827.2 & 291.9 & 267.6 & 73.0 & 7.3 \\
\hline M3 & 97.9 & 391.5 & 831.9 & 293.6 & 269.1 & 73.4 & 7.3 \\
\hline M4 & 297.0 & 198.0 & 841.5 & 297.0 & 272.2 & 74.3 & 7.4 \\
\hline M5 & 512.7 & 0.0 & 871.6 & 307.6 & 282.0 & 76.9 & 7.7 \\
\hline M2-A & 48.7 & 437.9 & 827.2 & 291.9 & 267.6 & 73.0 & 7.3 \\
\hline M1-2 & 0.0 & 515.6 & 876.5 & 309.4 & 180.5 & 77.3 & 7.7 \\
\hline M2-2 & 51.9 & 466.8 & 881.8 & 311.2 & 181.6 & 77.8 & 7.8 \\
\hline M3-2 & 104.4 & 417.5 & 887.2 & 313.1 & 182.7 & 78.3 & 7.8 \\
\hline M4-2 & 211.3 & 317.0 & 898.1 & 317.0 & 184.9 & 79.2 & 7.9 \\
\hline M5-2 & 548.5 & 0.0 & 932.5 & 329.1 & 192.0 & 82.3 & 8.2 \\
\hline
\end{tabular}

TABLE 5: Development of compressive strength.

\begin{tabular}{lccccc}
\hline \multirow{2}{*}{ Mixture } & \multicolumn{2}{c}{ Compressive strength $(\mathrm{MPa})$} & 28-day & 28-day oven-dry density $\left(\mathrm{kg} / \mathrm{m}^{3}\right)$ \\
\hline M1 & 3-day & 7-day & 14-day & 28.1 & 1952.8 \\
M2 & 25.2 & 25.8 & 26.4 & 28.4 & 1861.1 \\
M3 & 26.0 & 27.1 & 27.5 & 30.1 & 1959.0 \\
M4 & 22.4 & 25.7 & 25.8 & 16.4 & 1996.1 \\
M5 & 9.7 & 12.7 & 14.0 & 10.0 & 2118.1 \\
M2-A & 8.4 & 8.8 & 9.2 & 25.8 & 1941.2 \\
M1-2 & 5.1 & 16.6 & 21.6 & 17.3 & 1947.7 \\
M2-2 & 15.7 & 16.5 & 16.8 & 16.4 & 1971.2 \\
M3-2 & 5.5 & 10.1 & 13.1 & 14.6 & 1997.3 \\
M4-2 & 4.3 & 8.3 & 12.3 & 9.7 & 1996.8 \\
M5-2 & 7.8 & 8.7 & 9.2 & 8.6 & 2151.7 \\
\hline
\end{tabular}

which affect the strength development of OPSGC, were also carried out.

The coarse and fine aggregates were first mixed in a rotary concrete mixer for about 2 minutes; this was followed by the addition of the binders (FA and POFA) with further mixing for about 3 minutes. Next, the water, AK, and SP were gradually added and mixed for another 6 minutes. The wellmixed concrete was then poured into the steel moulds and compacted with vibration table. The specimens were then covered with plastic sheets to avoid evaporation of the surface water. After that, the oven-cured (oven temperature of $65^{\circ} \mathrm{C}$ ) and ambient-cured (laboratory temperature of about $30^{\circ} \mathrm{C}$ ) specimens are cured for 48 hours before being demoulded and tested.

2.3. Test Methods. The concrete specimens were cast in $100 \mathrm{~mm}$ cubes for the compressive test, which was carried out at the ages of $3,7,14$, and 28 days, in accordance with BS EN 12390-3 [17]. The tests on splitting tensile and flexural strengths were conducted based on ASTM C496 [18] and ASTMC78 [19], respectively. These tensile strength tests were carried out on cylinders of size $100 \phi \times 200 \mathrm{~mm}$ and prism of size $100 \times 100 \times 500 \mathrm{~m}$, correspondingly.

\section{Results and Discussion}

3.1. Effect of POFA on Strength Development of OPSGC. The development of the compressive strength for all OPSGC mixtures is presented in Table 5. From Figure 1, it is seen that the 28-day compressive strength of the OPSGC increases as the replacement of FA with POFA up to $20 \%$ for $0.55 \mathrm{AK} / \mathrm{B}$ ratio by mass. This phenomenon is attributed to the higher content of silica $\left(\mathrm{SiO}_{2}\right)$ and higher fineness of POFA, which enhanced the geopolymerization of the binders. Sata et al. [9] found similar trend where POFA increases the production of calcium silicate hydrate $(\mathrm{CSH})$ by reacting with calcium hydroxide $\left(\mathrm{Ca}(\mathrm{OH})_{2}\right)$, which improved the strength of the conventional concrete. The high fineness of POFA had greater pozzolanic reaction and acted as filler in voids; thus, it increased the compressive strength of the concrete [8]. On the other hand, the strength development showed a declining trend with a further replacement of FA with POFA (M4 and M5). Ariffin et al. [20] described that the low strength in the geopolymer concrete with high POFA content may be attributed to the incomplete geopolymerization due to its lower content of $\mathrm{Al}_{2} \mathrm{O}_{3}$. This is because $\mathrm{Al}_{2} \mathrm{O}_{3}$ tends to dissolve at higher rate during the early stage of geopolymerization. The low strength in the mixes M4 and M5, which 


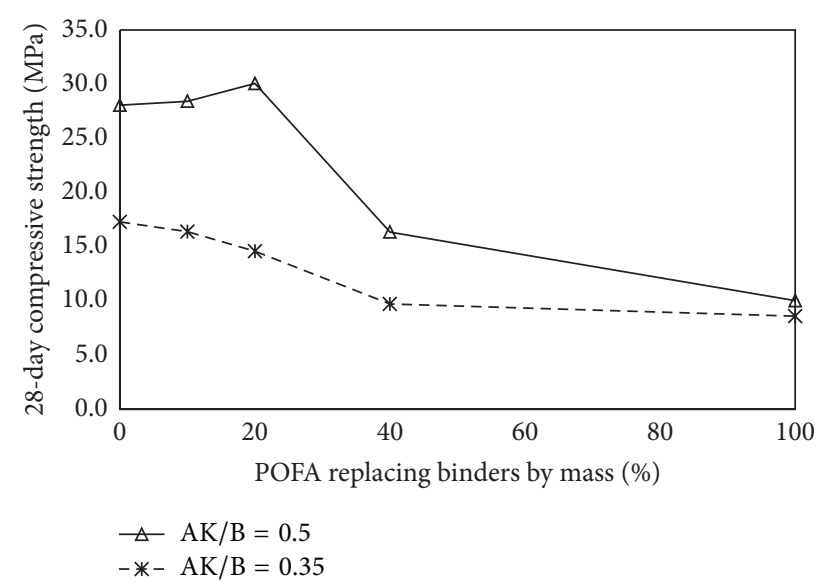

FIGURE 1: Effect of POFA on 28-day compressive strength.

contain high level of POFA, may also be attributed to the deficiency of the filler effect of POFA and the low availability of $\mathrm{Al}_{2} \mathrm{O}_{3}$ content for geopolymerization.

As seen in Table 5, the 3-day compressive strength of M2 is higher than that of both M1 and M3, which may be due to the higher efficiency of filler effect by POFA and higher dissolution rate of FA compared to that of POFA that contributes to a higher early strength. Tonnayopas et al. [21] reported that the lower early compressive strength is due to the slow pozzolanic activity of POFA. However, M3 with 20\% of POFA content produced the highest 28-day compressive strength and similar finding has been reported by Sata et al. [9]. Further, Table 5 shows that all the mixtures of the OPSGC fulfil the requirement for LWC as the oven-dry densities are lower than $2000 \mathrm{~kg} / \mathrm{m}^{3}$ as per the BS EN 206-1 [22] except for the M5 and M5-2. The use of 100\% POFA in the mixes M5 and M5-2 exhibited the highest density.

3.2. Effect of Curing Methods on Strength Development of OPSGC. It is clearly seen from Figure 2 that the oven-cured OPSGC, M2, exhibited higher compressive strength than the ambient-cured OPSGC, M2-A. Nevertheless, the main observation is the high early (3-day) compressive strength gained by M2, which is about $91 \%$ of its 28 -day compressive strength; however, the mix M2-A achieved only about $20 \%$ of its 28-day compressive strength. This denotes that the rate of the geopolymerization is accelerated by elevated temperature at early stage [23]. However, the strength of M2 does not develop exponentially compared to the strength of M2-A; this could be attributed to the high rate of geopolymerization during 48 hours of oven curing and this rate reduces after 48 hours. Similarly, Kusbiantoro et al. [24] reported that the oven-cured geopolymer concrete at $65^{\circ} \mathrm{C}$ exhibited superior mechanical properties compared to the other curing methods-ambient and external exposure. They reasoned that this could be attributed to the oven curing as the suitable condition to accelerate the dissolution and polycondensation of aluminosilicate gel in geopolymer framework.

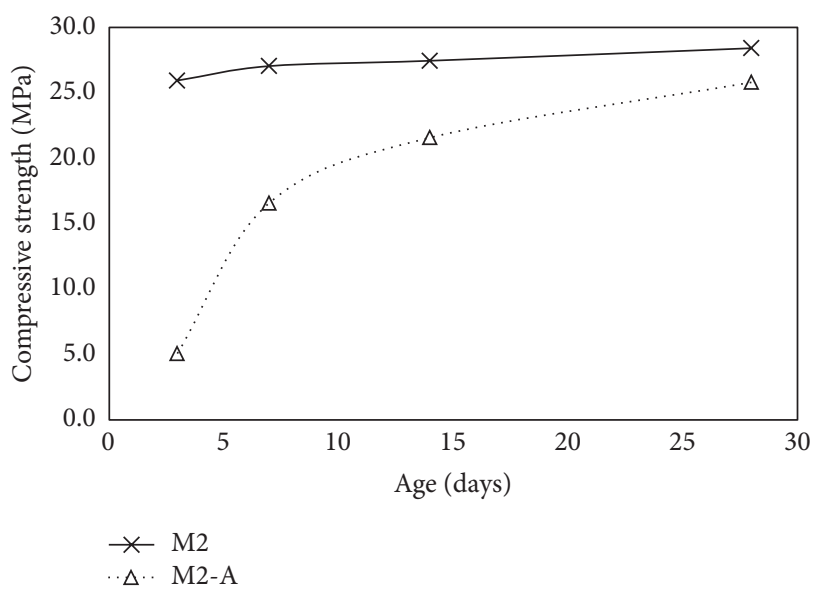

FIGURE 2: Effect of curing methods on the strength development.

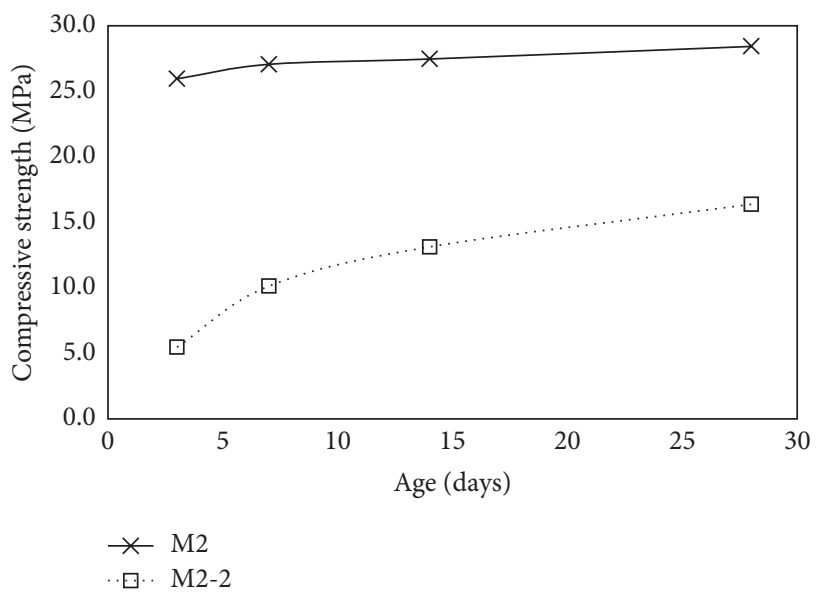

FIGURE 3: Effect of ratio of AK/B by mass on the strength development.

3.3. Effect of Alkaline Solution to Binders Ratio by Mass on Strength Development of OPSGC. Figures 1 and 3 show that in general all the mixes with $\mathrm{AK} / \mathrm{B}$ ratios of 0.55 are of higher strength compared to the mixes with low $\mathrm{AK} / \mathrm{B}$ ratio of 0.35 . The increase of the ratio of $\mathrm{AK} / \mathrm{B}$ by mass increases the ratio of $\mathrm{SiO}_{2} / \mathrm{Al}_{2} \mathrm{O}_{3}$ that results in higher rate of geopolymerization and formation of denser structure, which leads to a higher compressive strength. Abdullah et al. [25] investigated that the ratio of $\mathrm{AK} / \mathrm{B}$ of 0.5 by mass produces higher compressive strength than the ratio of 0.67 and 0.4 . Sathonsaowaphak et al. [3] found that a very low compressive strength of $8 \mathrm{MPa}$ was achieved for the mix with the AK/B ratio of 0.325 by mass; however, they reported that the high compressive strengths were in the range of 42 to $52 \mathrm{MPa}$ as the ratios of $\mathrm{AK} / \mathrm{B}$ by mass were varied between 0.429 and 0.709 .

3.4. Tensile Strength of OPSGC. The results of the splitting tensile and flexural strengths of all the OPSGC mixtures are shown in Table 6 . The results of the tensile strength showed a comparable trend with the results of 28-day compressive strength. The mix, M3, produced the highest splitting tensile 
TABLE 6: Tensile strength of OPSGC.

\begin{tabular}{lcc}
\hline Mixture & \multicolumn{2}{c}{ Tensile strength $(\mathrm{MPa})$} \\
& Splitting tensile & Flexural \\
\hline M1 & 2.12 & 3.55 \\
M2 & 2.13 & 3.70 \\
M3 & 2.41 & 3.74 \\
M4 & 1.62 & 3.11 \\
M5 & 1.27 & 1.95 \\
M2-A & 2.03 & 3.31 \\
M1-2 & 1.66 & 2.65 \\
M2-2 & 1.62 & 2.55 \\
M3-2 & 1.53 & 2.36 \\
M4-2 & 1.25 & 1.93 \\
M5-2 & 1.17 & 1.85 \\
\hline
\end{tabular}

and flexural strengths of 2.41 and $3.74 \mathrm{MPa}$, respectively. The oven curing of the specimens combined with high AK/B ratio of 0.55 by mass may have aided the dissolution and polycondensation process of the geopolymer framework. This could have led to enhancing the rate of production of amorphous aluminosilicate gel and hence improved the mechanical properties. The ratio of splitting tensile strength to compressive strength $\left(f_{t} / f_{\mathrm{cu}}\right)$ of M1, M2, M3, and M2-A is varied from 0.075 to 0.08 , which showed comparable results reported by Alengaram et al. [26]. Alengaram et al. [27] also stated that the low ratio of $f_{t} / f_{\mathrm{cu}}$ could be due to the porous OPS. Conforming to ASTM C330 [28], the mixes M1, M2, and M3 meet the requirement as structural LWC. Furthermore, (1) proposed by Neville [29] to estimate the splitting tensile strength for LWAC with the compressive strength of 10 to $65 \mathrm{MPa}$ can be used for OPSGC since it gives close results. Consider

$$
f_{t}=0.23^{3} \sqrt{f_{\mathrm{cu}}^{2}}
$$

where $f_{t}$ is the 28-day splitting tensile strength of the test specimen $(\mathrm{MPa})$ and $f_{\mathrm{cu}}$ is the 28-day compressive strength of the test specimen ( $\mathrm{MPa})$.

The percentages of flexural strength to compressive strength $\left(f_{r} / f_{\mathrm{cu}}\right)$ found in this investigations ranged from 12.4 to $21.5 \%$. Similar to splitting tensile strength results, a comparable ratio of $f_{r} / f_{\mathrm{cu}}$ with the results reported by Shafigh et al. [30] is only applicable to few mixtures such as M1, M2, M3, and M2-A. Further, the flexural strength of 3.74 obtained for the mix M5 shows the significance of the percentage of POFA used in the mixes. The increase of the POFA content up to $20 \%$ increases the strength for both 0.35 and 0.55 of AK/B ratios. However, any further replacement of FA with POFA decreases the strength, which could be attributed to the lower void ratio to occupy the fine particles.

\section{Conclusions}

Based on the experimental results obtained from this research, the following conclusions can be drawn. (i) The OPSGC mixture with POFA content of up to $40 \%$ could be considered as LWC as the oven-dry density is found to be lower than $2000 \mathrm{~kg} / \mathrm{m}^{2}$ for both mixtures which contain 0.55 and 0.35 as $\mathrm{AK} / \mathrm{B}$ ratios. However, an increase of the POFA content beyond $40 \%$ increases the concrete density.

(ii) The compressive and tensile strengths of the OPSGC increased with the POFA content up to $20 \%$ and further replacement of POFA showed a significant reduction in the strength.

(iii) The oven curing enhanced the early strength of the OPSGC up to $91 \%$; however, there is a higher strength gain over time for the ambient-cured OPSGC.

(iv) The use of $\mathrm{AK} / \mathrm{B}$ ratio of 0.55 by mass contributes to dissolution and polycondensation in geopolymer framework that produced higher compressive strength of OPSGC compared to mixes with low $\mathrm{AK} / \mathrm{B}$ ratio of 0.35 .

(v) The mix, M3, with $20 \%$ of POFA content along with $\mathrm{AK} / \mathrm{B}$ ratio of 0.55 and oven curing is recommended as optimum mix as it produced the highest strength among others.

(vi) The minimum requirement of $2.0 \mathrm{MPa}$ of the splitting tensile strength was achieved for the mixes with low POFA content of less than $20 \%$.

(vii) Both the splitting and flexural tensile strengths of the OPSGC showed acceptable values for LWAC.

\section{Conflict of Interests}

The authors declare that there is no conflict of interests regarding the publication of this paper.

\section{Acknowledgments}

This research work was funded by the University of Malaya under the University of Malaya Research Grant (UMRG) no. RP018-2012B (development of geopolymer concrete for structural application). The authors are grateful to the ViceChancellor of the University of Malaya for his noteworthy effort in securing the funding for the above mentioned project.

\section{References}

[1] X. Ma and Q. Rao, "Mechanical properties of high-performance lightweight aggregate concrete with inorganic polymers cement based on multiple minerals under uniaxial loading," Advances in Materials Science and Engineering, vol. 2012, Article ID 453035, 5 pages, 2012.

[2] J. Davidovits, "Chemistry of geopolymeric systems, terminology," in Proceedings of the International Conference Geopolymere, pp. 9-37, Saint-Quentin, France, 1999.

[3] A. Sathonsaowaphak, P. Chindaprasirt, and K. Pimraksa, "Workability and strength of lignite bottom ash geopolymer mortar," Journal of Hazardous Materials, vol. 168, no. 1, pp. 4450, 2009. 
[4] S. E. Wallah and B. V. Rangan, "Low calcium fly ash based geopolymer concrete: long term properties," Research Report GC 2, Curtin University of Technology, Perth, Australia, 2006.

[5] P. Shafigh, M. Z. Jumaat, H. B. Mahmud, and U. J. Alengaram, "A new method of producing high strength oil palm shell lightweight concrete," Materials and Design, vol. 32, no. 10, pp. 4839-4843, 2011.

[6] U. J. Alengaram, B. A. Al-Muhit, M. Z. Jumaat, and M. Y. J. Liu, "A comparison of the thermal conductivity of oil palm shell foamed concrete with conventional materials," Materials \& Design, vol. 51, pp. 522-529, 2013.

[7] S. P. Yap, U. J. Alengaram, and M. Z. Jumaat, "Enhancement of mechanical properties in polypropylene- and nylon-fibre reinforced oil palm shell concrete," Materials \& Design, vol. 49, pp. 1034-1041, 2013.

[8] W. Tangchirapat, T. Saeting, C. Jaturapitakkul, K. Kiattikomol, and A. Siripanichgorn, "Use of waste ash from palm oil industry in concrete," Waste Management, vol. 27, no. 1, pp. 81-88, 2007.

[9] V. Sata, C. Jaturapitakkul, and K. Kiattikomol, "Utilization of palm oil fuel ash in high-strength concrete," Journal of Materials in Civil Engineering, vol. 16, no. 6, pp. 623-628, 2004.

[10] M. A. M. A. Raden and M. S. Hamidah, "Strength characteristic of foamed geopolymer concrete," in Proceedings of the 11th International Conference on Concrete Engineering and Technology, Putrajaya, Malaysia, 2012.

[11] R. H. Kupaei, U. J. Alengaram, M. Z. Jumaat, and H. Nikraz, "Mix design for fly ash based oil palm shell geopolymer lightweight concrete," Construction and Building Materials, vol. 43, pp. 490-496, 2013.

[12] M. A. M. Ariffin, M. A. R. Bhutta, M. W. Hussin, M. M. Tahir, and N. Aziah, "Sulfuric acid resistance of blended ash geopolymer concrete," Construction and Building Materials, vol. 43, pp. 80-86, 2013.

[13] ASTM C618, Standard Specification for Coal Fly Ash and Raw or Calcined Natural Pozzolan for Use in Concrete, ASTM International, West Conshohocken, Pa, USA, 2012.

[14] M. W. Hussin and T. Ishida, "A study on basic properties of hardened concrete containing palm oil fuel ash as partial cement replacement material," in Proceedings of the Annual Meeting in Materials and Construction, Summaries of Technical, pp. 179-180, Architectural Institute of Japan, Tokyo, Japan, 1999.

[15] ASTM C136, Standard Test Method for Sieve Analysis of Fine and Coarse Aggregates, ASTM International, West Conshohocken, $\mathrm{Pa}, \mathrm{USA}, 2001$.

[16] U. J. Alengaram, B. A. Al-Muhit, and M. Z. Jumaat, "Utilization of oil palm kernel shell as lightweight aggregate in concrete-a review," Construction and Building Materials, vol. 38, pp. 161172, 2013.

[17] BS EN 12390-3, Testing Hardened Concrete Compressive Strength of Test Specimens, British Standards Institution, London, UK, 2002.

[18] ASTM C496, Standard Test Method for Splitting Tensile Strength of Cylindrical Concrete Specimens, ASTM International, West Conshohocken, Pa, USA, 2011.

[19] ASTM C78, Standard Test Method for Flexural Strength of Concrete (Using Simple Beam with Third-Point Loading), ASTM International, West Conshohocken, Pa, USA, 2010.

[20] M. A. M. Ariffin, M. W. Hussin, and M. A. R. Bhutta, "Mix design and compressive strength of geopolymer concrete containing blended ash from agro-industrial wastes," Advanced Materials Research, vol. 339, no. 1, pp. 452-457, 2011.
[21] D. Tonnayopas, F. Nilrat, K. Putto, and J. Tantiwitayawanich, "Effect of oil palm fiber fuel ash on compressive strength of hardening concrete," in Proceedings of the 4th Thailand Materials Science and Technology Conference, pp. 1-3, Pathumthani, Thailand, 2006.

[22] BS EN 206-1, Concrete Specification, Performance, Production and Conformity, British Standards Institution, London, UK, 2000.

[23] J. C. Swanepoel and C. A. Strydom, "Utilisation of fly ash in a geopolymeric material," Applied Geochemistry, vol. 17, no. 8, pp. 1143-1148, 2002.

[24] A. Kusbiantoro, M. F. Nuruddin, N. Shafiq, and S. A. Qazi, "The effect of microwave incinerated rice husk ash on the compressive and bond strength of fly ash based geopolymer concrete," Construction and Building Materials, vol. 36, pp. 695703, 2012.

[25] M. M. A. Abdullah, H. Kamarudin, H. Mohammed, I. Khairul Nizar, A. R. Rafiza, and Y. Zarina, "The relationship of $\mathrm{NaOH}$ molarity, $\mathrm{Na}_{2} \mathrm{SiO}_{3} / \mathrm{NaOH}$ ratio, fly ash/alkaline activator ratio, and curing temperature to the strength of fly ash-based geopolymer," Advanced Materials Research, vol. 328-330, pp. 1475-1482, 2011.

[26] U. J. Alengaram, H. Mahmud, M. Z. Jumaat, and S. M. Shirazi, "Effect of aggregate size and proportion on strength properties of palm kernel shell concrete," International Journal of Physical Sciences, vol. 5, no. 12, pp. 1848-1856, 2010.

[27] U. J. Alengaram, H. Mahmud, and M. Z. Jumaat, "Enhancement and prediction of modulus of elasticity of palm kernel shell concrete," Materials and Design, vol. 32, no. 4, pp. 2143-2148, 2011.

[28] ASTM C330, Standard Specification for Lightweight Aggregates for Structural Concrete, ASTM International, West Conshohocken, Pa, USA, 2009.

[29] A. M. Neville, Properties of Concrete, 4th and Final Edition, Pearson Education Limited, Harlow, UK, 1997.

[30] P. Shafigh, M. Z. Jumaat, H. B. Mahmud, and N. A. A. Hamid, "Lightweight concrete made from crushed oil palm shell: tensile strength and effect of initial curing on compressive strength," Construction and Building Materials, vol. 27, no. 1, pp. 252-258, 2012. 

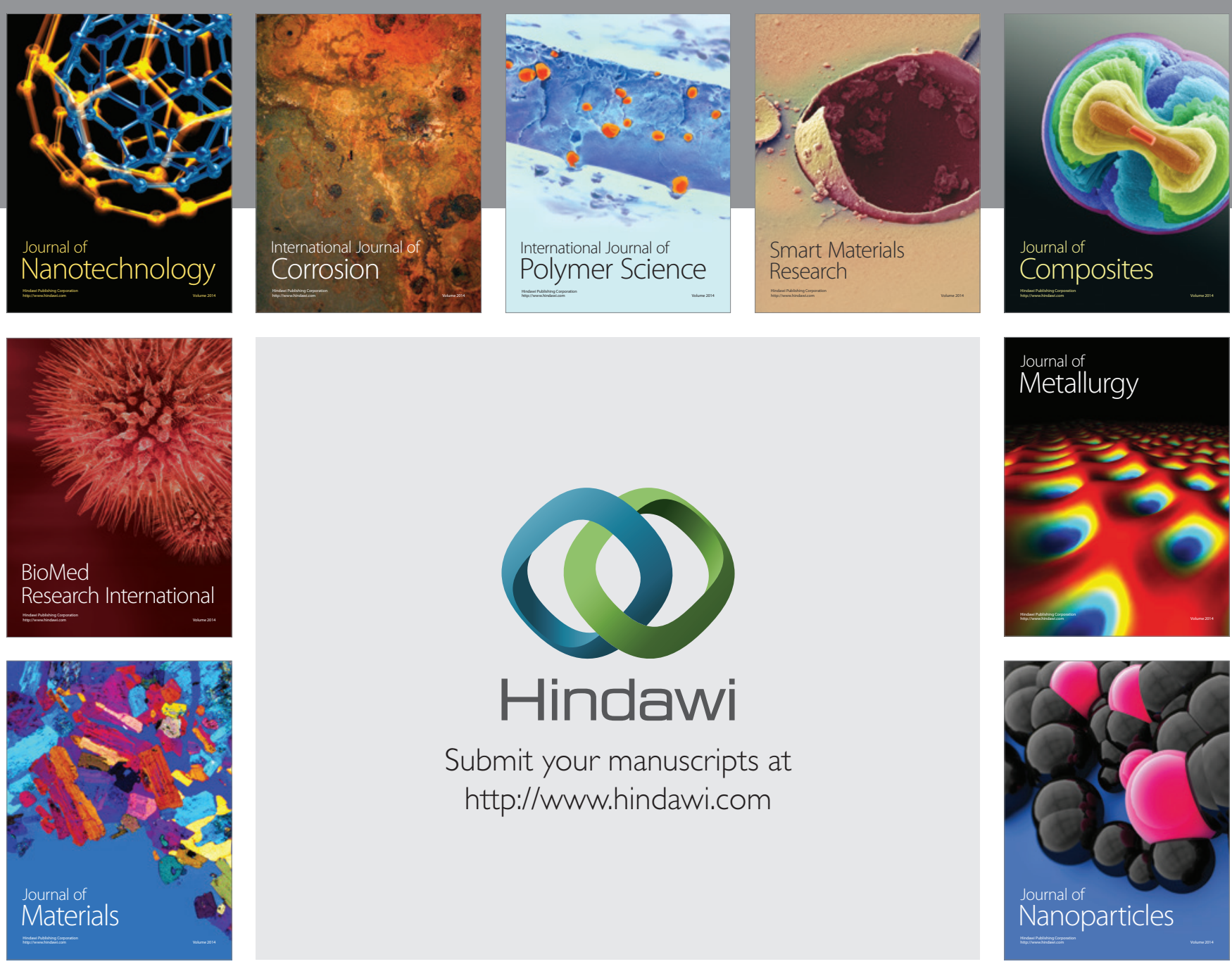

Submit your manuscripts at http://www.hindawi.com
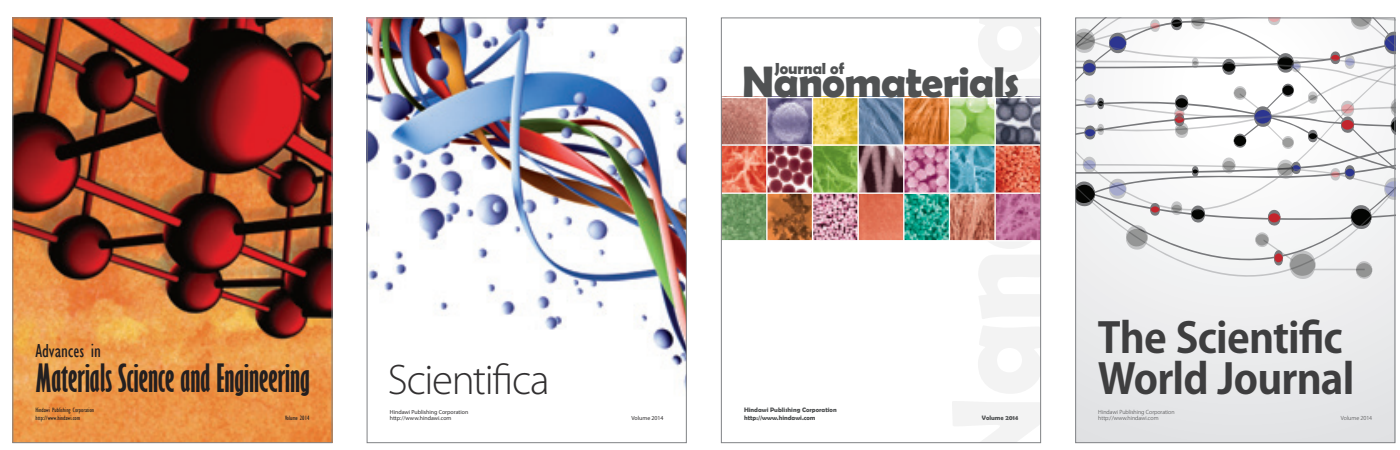

\section{The Scientific World Journal}
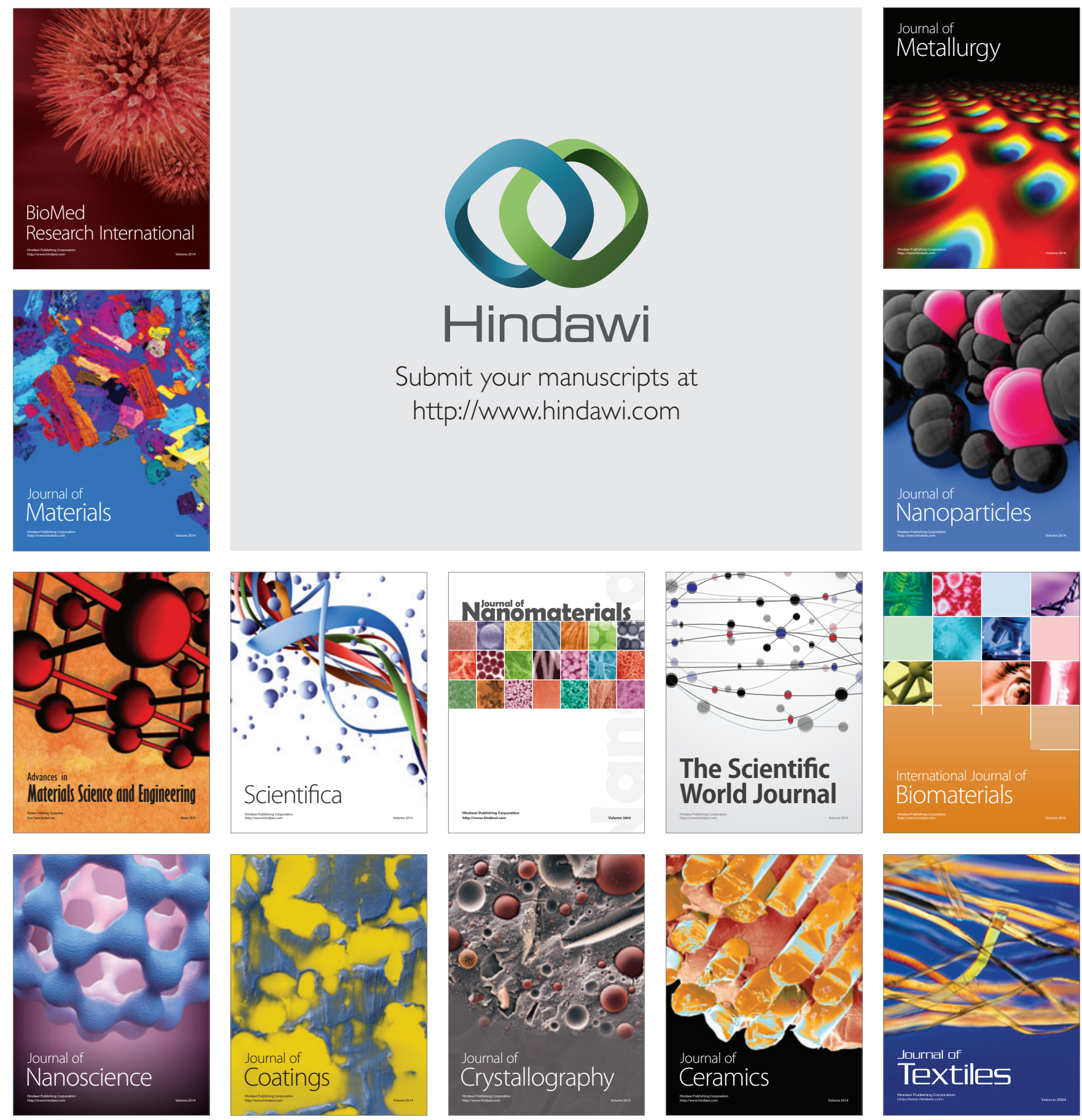